\title{
Design of Automated Process in Supply Chain Application based on Supplier's Ranked and Quota
}

\author{
Putu Angelina Widya G. \\ Scholar \\ Dept of Information \\ Technology, Udayana \\ University, Indonesia
}

\author{
I Made Sukarsa, ST.,MT \\ Lecturer \\ Dept of Information \\ Technology, Udayana \\ University, Indonesia
}

\author{
I Nyoman Piarsa, ST.,MT \\ Lecturer \\ Dept of Information \\ Technology, Udayana \\ University, Indonesia
}

\begin{abstract}
The world is in an era of competitive supply chain, in which the organization is no longer acting in isolation as an independent entity, but as the supply chain to create value delivery systems that are more responsive to market changes faster, more consistent and reliable. This paper focuses on the automation process for supplier's selection when supply process that customers do in a wholesaler. First, suppliers were rated manually to inform the process that the highest ranking have a good reputation in the provision of products and timeliness of supply. In addition, the supplier also include how much product's quota they have which can be supplied in booking transactions on the same time.
\end{abstract}

\section{Keywords}

Supply Chain, web application, automated process, ranking, quota

\section{INTRODUCTION}

Successful companies marked by how serious they manage aspects of supply chain management. The reason is that the supply chain management means the company has tried to do customer service strategy with a professional and highly effective. Consumers will be well served if the company has the ability to manage the necessary resources to provide the best service for consumers. The company is able to manage delivery of goods and services in a timely manner and be able to perform continuously.

Delivery's issue of goods and services, not only affected by internal problems. However, influenced by the cooperation between relevant actors. Synergies between companies and suppliers is necessary, as well as transportir to provide the best service to consumers. So the company will have the ability to compete in the future.

When the company has entered into the global market, the expansion of the supply chain which is owned be a strategic challenge. Plan strategies on supply chain management can be successful, if the supply chain is flexible in the sense quite reactive to changes in the existing supplier selection example by doing in supplying products to the consumer automatically based on the results of their work and loyalty over the years. The state of the global market, which means the fulfillment of information can be done anywhere and at any time require a breakthrough in the use of information technology to retrieve data directly from the consumer demand and deliver it to the supplier and transportir involved in order fulfillment and delivery.

\section{LITERATURE REVIEW}

Michael N. Huhns, Larry M. Stephens, and Nenad Ivezic explores a linguistic approach to coordination modeling as a formal basis for supply chain management (SCM) in manufacturing. They described here promote the interchange of standard business documents and compensate for exceptions that might occur during execution. Enterprises need only describe their supply processes using standard business documents and UML interaction diagrams. The methodologies and tools convert the diagrams into specifications for software agents, which then cooperate in automating the resultant supply chain. This investigation has also identified additional work that needs to be done in order to refine the methodology, demonstrate its utility, and foster its adoption.

Martin Verwijmeren present a software component architecture for supply chain management across dynamic organizational networks. Local management in the architecture is done with enterprise resource planning systems (ERP), warehouse management system (WMS) and transportation management system (TMS). Integral management in the architecture is executed by supply chain engines (SCES). Software components to form a supply chain system that runs on top of ERP, WMS and TMS. The SCES has the knowledge and flexibility needed to manage the dynamic supply chain. Software component architecture can be implemented with technology for components, and interfaces available in Java Enterprise, CORBA and Web Services.

Luis H. Bibiano, Alberto Caldelas, Enric Mayol and Joan A. Pastor say Supply Chain Management (SCM) System is a packaged technological solution that, after its deployment, it offers to the organization several advantages to coordinate their raw material acquisition, production and logistic processes, and at the same time, it improves relationship with customer and suppliers, building longterm strategic alliances. SCM system can define as the technological solution that manages and give support to activities related with product delivery, from raw material management until the final product reaches the end customer. It includes processes for raw material acquisition, production and assembly, storage, inventory control, order management, distribution along commercial channels and customer delivery. A SCM system will allow the organization to automate and control in a better way processes related to product acquisition, production and warehousing in order to obtain the desired benefits. In order to achieve these benefits, an implementation process is required.

Ritu Sindhu, Abdul Wahid, and GN Purohit found that the level of coordination between organizations on strategic, 
tactical and operations levels lead to more effective and efficient supply chain. Supply chain management is increasing day by day in modern enterprises, the environment becomes competitive and many companies will be hard to survive if they do not make their source, production and distribution more efficient.

David Zhu tells that information sharing as an important field of study in supply chain management is typically studied using standard mathematic approaches that focus on the equilibrium states of a system. Apart from many significantly important advantages of the traditional approaches, one major drawback of them is the lack of flexibility to accommodate dynamic interactive activities in the systems and thus, due to such interactions, the dynamics and commonly computationally intractable nature of the systems is partially or totally ignored.

Dilay Celebi, Sotiris Politis and Matthias Klumpp stated that the supplier selection can improve the competitiveness of enterprises and business development. Feedback is given to suppliers that the company aims to provide an assessment of the integrity which are the supplier of cooperation can be trusted to avoid the risk of losses obtained choose the wrong supplier.

\section{SUPPLY CHAIN MANAGEMENT}

The era of globalization is full of competition not only in domestic but international reach, making the organization or company looking for ways to make or produce high-value products for customers. Not only the physical product to look good, but also how the service provided for the customer to consider such as how to make customers feel satisfied and keep in contact with the company. In addition, the efficiency and effectiveness issue costs incurred to produce or sell should also be considered so that the goods can be sold at low prices, quality and good service. [5]

\subsection{Differences of Logistics Management with Supply Chain Management}

Logistics process is closely related to daily life activities directly or indirectly. This process is not only experienced in the factory but also the society. For example, when consumers receive transaction orders the wrong item, food that does not arrive on time due to limited transportation and storage facilities resulting in additional costs or lack of satisfaction to these services. It requires a management approach in logistics is to search for solutions in a chain of goods flow which allows the movement of goods from the producer to the consumer so that the things mentioned earlier can be reduced or even eliminated. [11]

During this Supply Chain Management is often defined as a logistics management when there is a difference between the two. The Council of Logistics Management (CLM) defines logistics management as part of the Supply Chain process that serves to plan, implement and control the efficiency and effectiveness of the flow and storage of goods, services and related information from the point of beginning (point-oforigin) to the point consumption (point-of-consumption) in its aim to meet the needs of its customers.

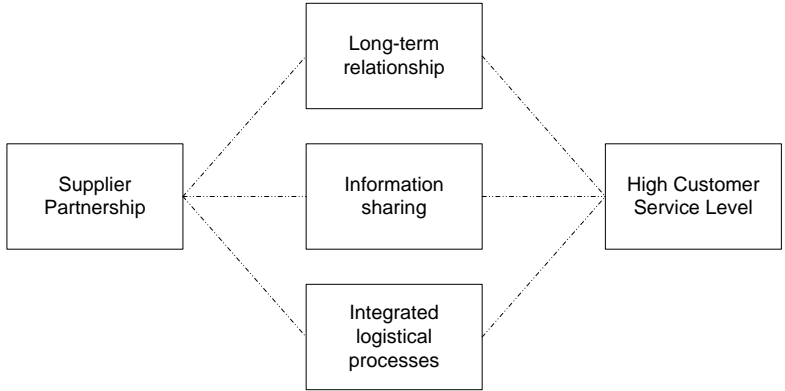

Fig. 1 Model of Supply Chain Management

While the Supply Chain Management integration was not enough flow of product and information on the company's internal only, customers and suppliers are also taking part in the integration. The main objective of Supply Chain Management is to reduce or even eliminate the inventory buffer between several departments involved in a chain by sharing information on demand and current inventory.

Supply Chain Management consists of three elements mutually bound to each other, namely supply chain network structure, supply chain business processes, and supply chain management components. The goal is to maximize competition and profit for the company and all its members, including the end consumer.

\subsection{Structure of Supply Chain Management}

A Supply Chain encompasses all companies and organizations associated with the company through suppliers or customers from point of origin to the origin of consumption.

The actors involved in a simple format that consists of only three players. Companies, suppliers, and consumers. But in the wider supply chain, there are additional players anymore. Their they are supplying its suppliers, while at their downstream are consumer's customers.

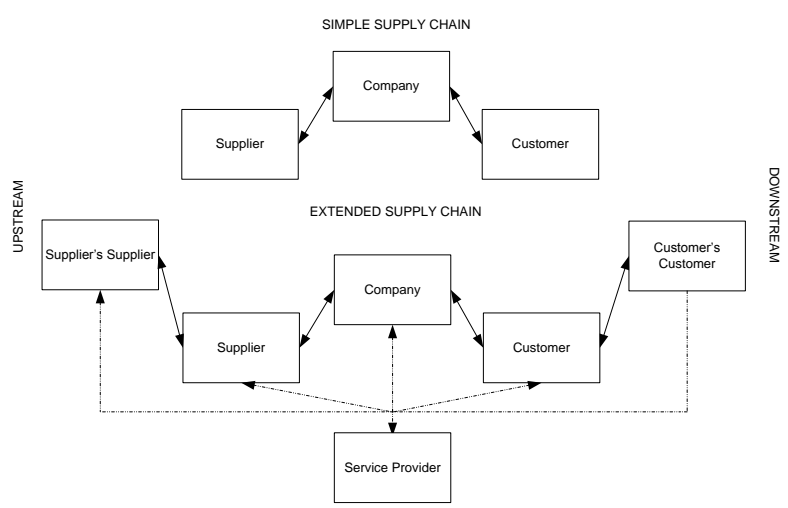

Fig. 2 Actors of Supply Chain Management.

Consumer in the supply chain can be a distributor, wholesaler or retailer. Distributor can be a company that takes inventory of manufacture and deliver it to consumers. Wholesaler or better known as the cash and carry market to buy products from distributors or manufacturers directly. They usually have a few specialized products and supplying specialized industries such as hotels, restaurants, and catering to the large quantity of each product. Retailer on the other hand, store the product in small quantities and sell them to the public.[9] 


\section{DESIGN AND ARCHITECTURE}

This section will explain how to design and architecture of the automation process of supplier selection in supply chain applications. The system design will use the UML concept and design of the database consists of ER diagram and table structure

\subsection{An Overview of Automated Supplier's Selection in Supply Chain Application}

The process on the application moved by the three actors, namely suppliers, consumers and wholesalers themselves. Wholesaler will tend to push towards the automation of the process that focuses on automatic information exchange (information automation). Automation of data flow that occurs between all stakeholders in the supply chain, allowing each transaction processed by the system. Here is an overview of the application and the explanation.

\begin{tabular}{|c|c|c|}
\hline \multicolumn{2}{|c|}{ PRODUCt OFFERING BY SUPPLER } \\
\hline $\begin{array}{c}\text { Wholesaler inputs } \\
\text { data of product } \\
\text { which be sold }\end{array}$ & $\begin{array}{c}\text { Application saves } \\
\text { data to database }\end{array}$ & $\begin{array}{c}\text { Registered supliers } \\
\text { propose list of product } \\
\text { that they want to supply } \\
\text { through the web pages. } \\
\text { They put how many } \\
\text { quota that they can } \\
\text { supply on the same time } \\
\text { of a kind product }\end{array}$ \\
$\begin{array}{c}\text { Wholesaler received } \\
\text { reports of additional new } \\
\text { supply and can alter the } \\
\text { ranking of suppliers }\end{array}$ & $\begin{array}{c}\text { automatically stores data } \\
\text { supplied products to the } \\
\text { database and puts } \\
\text { supplier's product to the } \\
\text { end rank }\end{array}$ & \begin{tabular}{c} 
The application \\
\hline
\end{tabular} \\
\hline
\end{tabular}

Fig. 3 Product Offering by Supplier

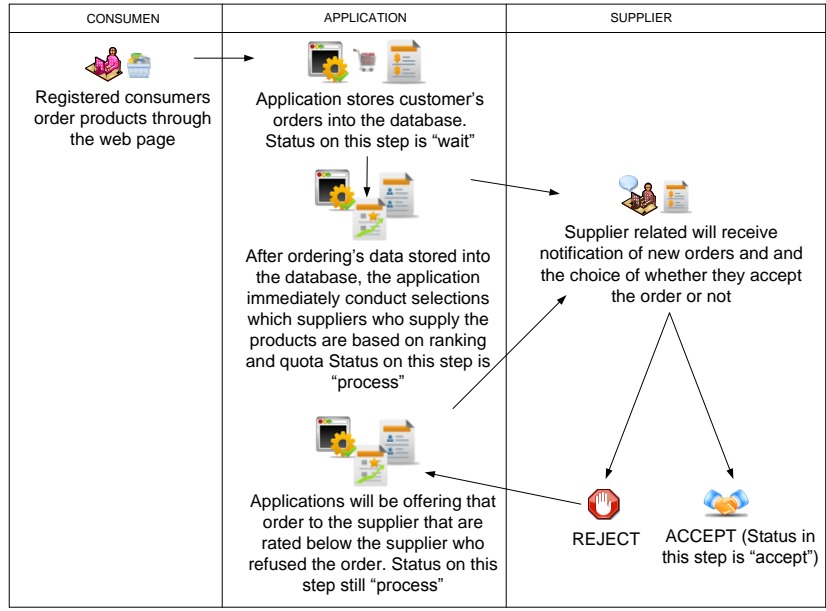

Fig. 4 Automated Process of Supplier's Selection When Consumer Order

After consumer makes order transaction, the application will automatically process the data transaction. Starting from the product in the first row, the system will look at how much the quantity of the order of that product. Then it will do a query to retrieve all suppliers that supply products and sorted according their rank. Starting from the first rank, the application will look in the table record supplier order to check whether the supplier has any order with same product and date. If there is, then the system will check whether the supplier is able to supply these products based quota it offers if they are still capable, that supplier is choosed but if not then the system will switch to the rank below it. But if it does not have a transaction, then the application will choose the supplier to supply them. And so on until all the products in one order is handled. For more details can be seen in the flowchart. 


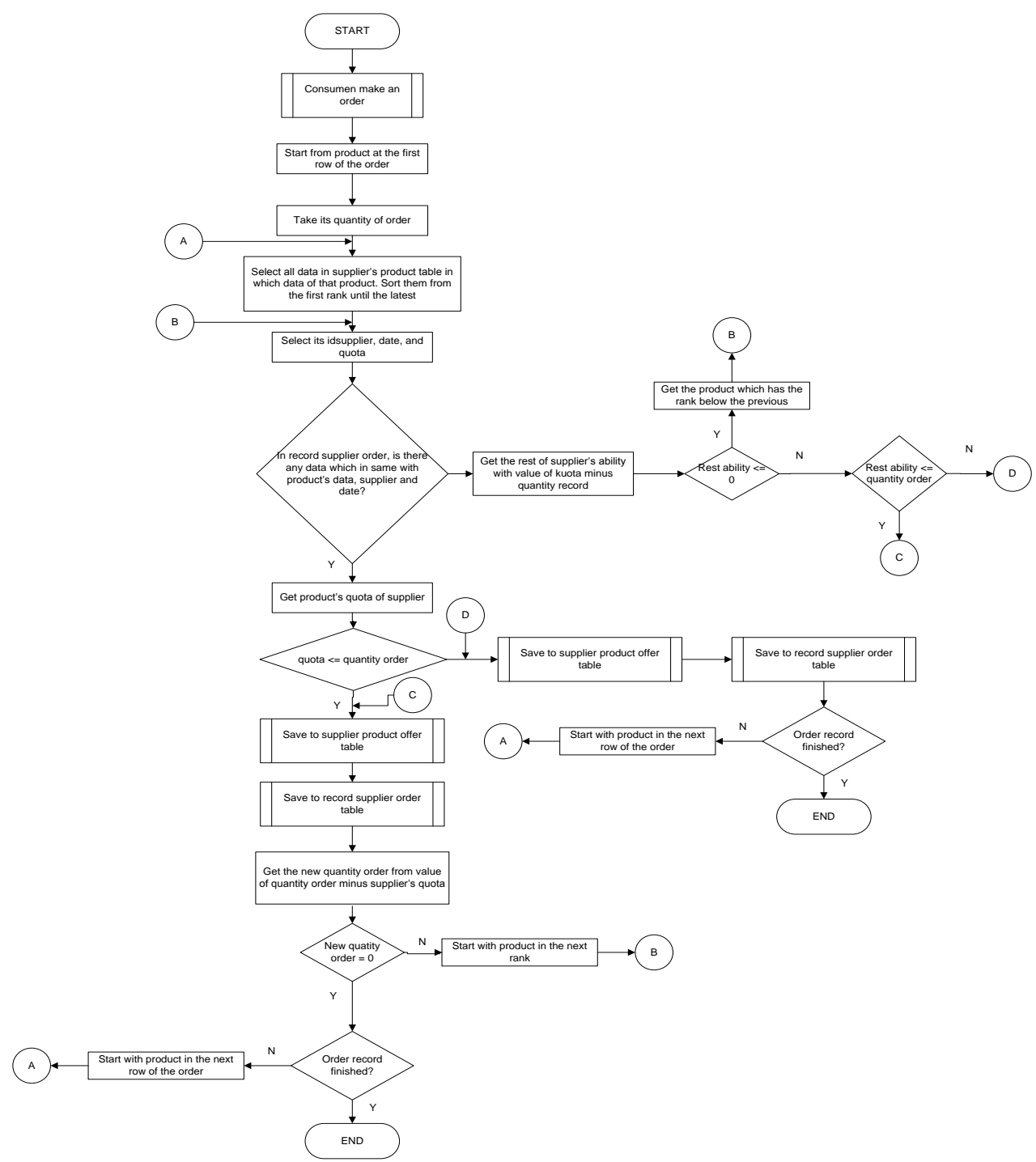

Fig. 5 Flowchart of Supplier's Selection

\subsection{Design of System}

The design of the application made by the concept of UML such as use case diagram, activity diagram, and class diagram.

Use-case diagram is a diagram for modeling aspects of system behavior. Each use-case diagram shows a set of use-cases, actors and relationships. Here is a picture of the use case model of supply chain application:

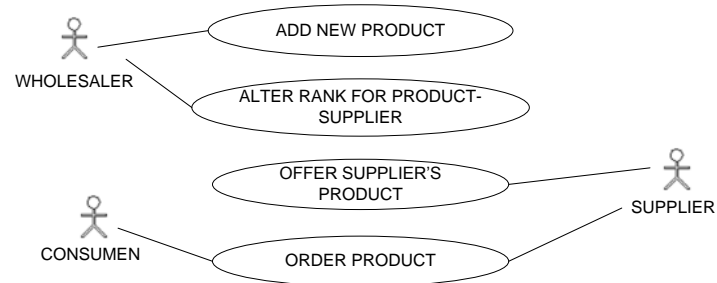

Fig. 6 Use Case Diagram

An activity diagram is essentially a fancy flowchart. Activity diagrams and statechart diagrams are related. The activity diagram shows the how those activities depend on one another. Here is a picture of the activity diagram in this application:

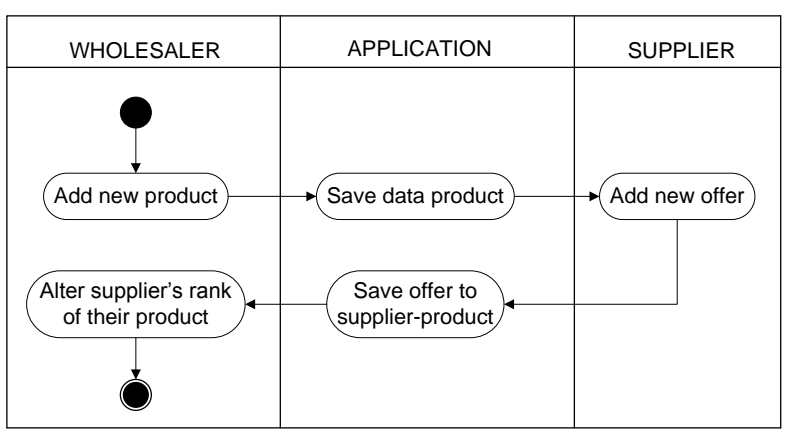

Fig. 7 Activity Diagram of Product Offering by Supplier 


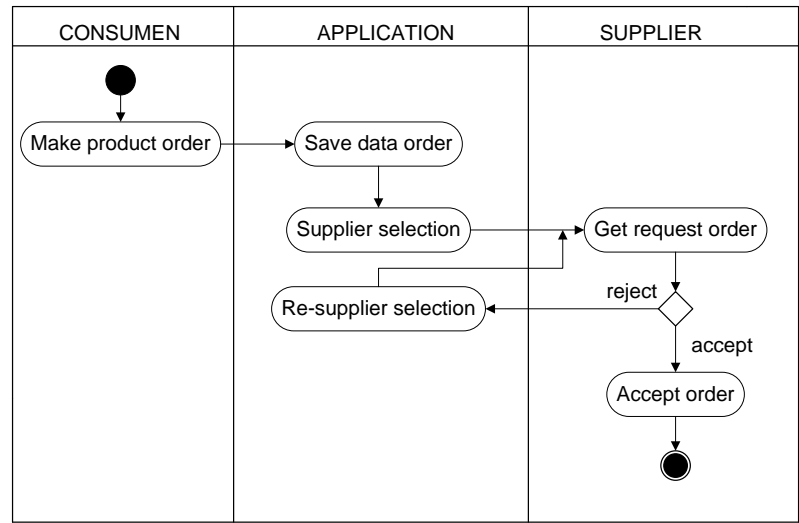

Fig. 8 Activity Diagram of Supplier's Selection When Consumer Order

A Class diagram gives an overview of a system by showing its classes and the relationships among them. Here is a picture of the sequence diagram in this application:

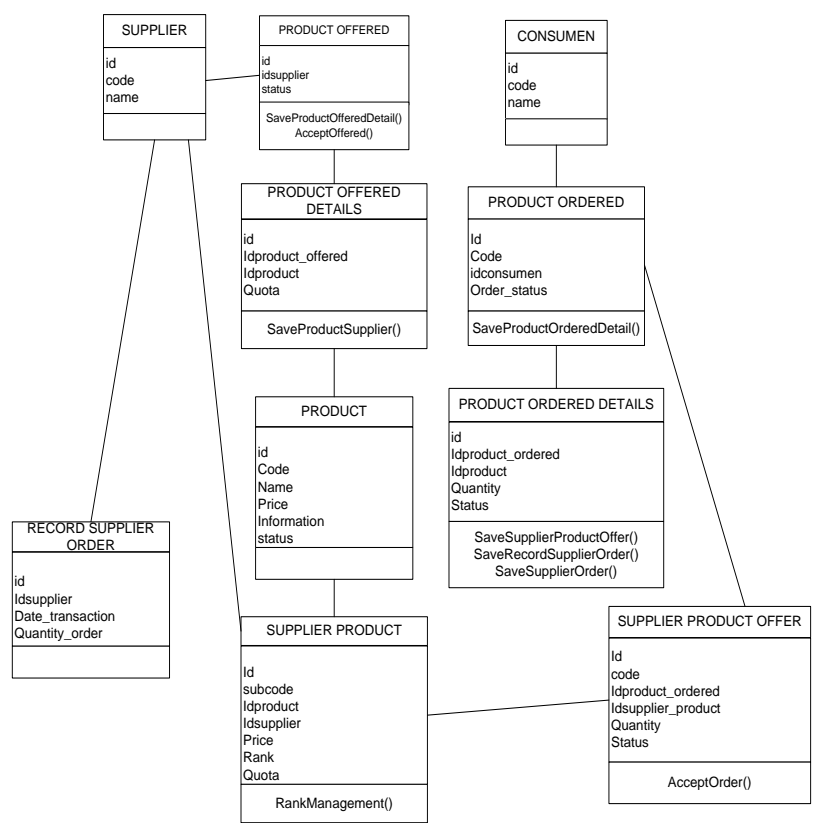

Fig. 9 Class Diagram of this application

\subsection{Design of Database}

Wholesaler only act as a quality control that can change the ranking based on the work and the trust of suppliers. Supplier offers products in product offered order. Then the entity of supplier's product accommodates the results of product offerings received. Supplier also has entity record supplier's order that records how many orders that a kind of product which are supplied in the same day. Consumers have order product entity where the entity is an entity associated with the product

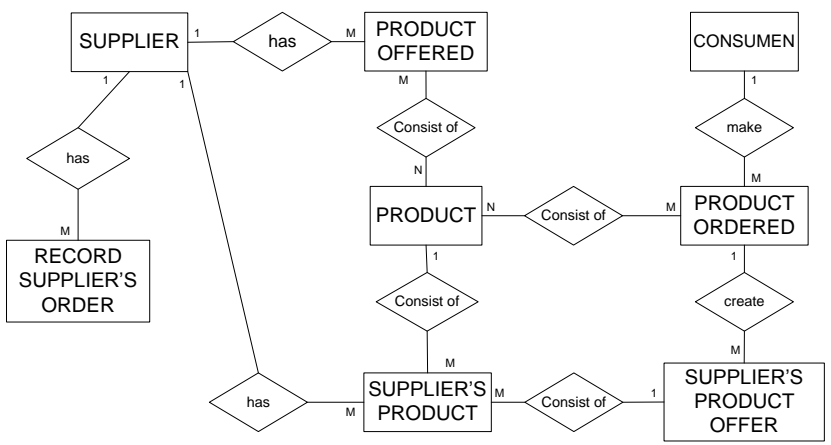

Fig. 10 ER Diagram of Process Automated in Supply Chain

Due to the many-to-many occur in the product offered and product ordered entity, it will display new tables that named offered product details and product ordered details. Both are connected to the product entity

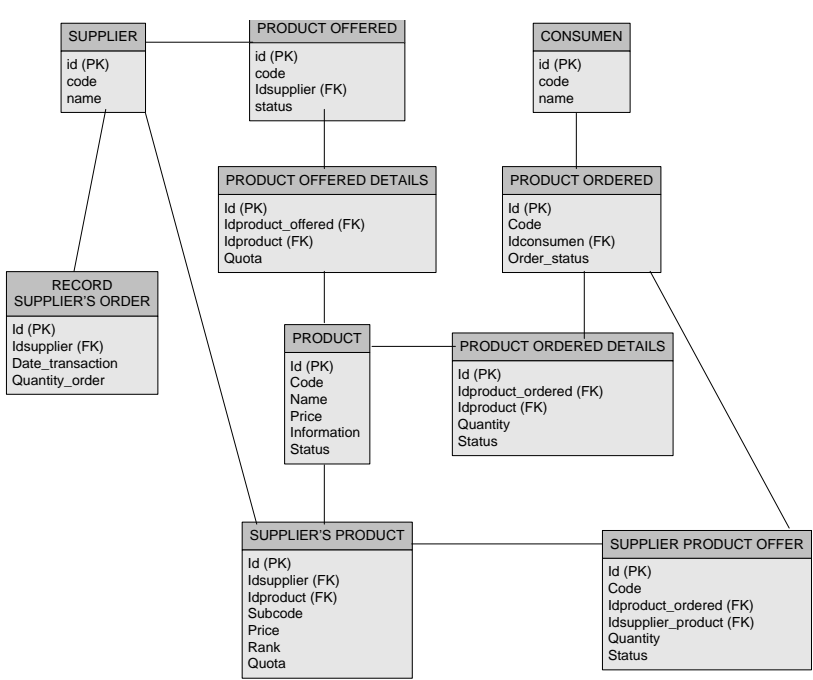

Fig. 11 ER Table Structures of Process Automated in Supply Chain

These are the descriptions of the data structure which used in the application's tables

Table 1. Data Structures in Supplier

\begin{tabular}{|c|c|c|}
\hline Field & Data Type & Validation \\
\hline ID & int & PK \\
\hline Code & Varchar(5) & - \\
\hline Name & Varchar(50) & - \\
\hline
\end{tabular}

Table 2. Data Structures in Record Supplier'sOrder

\begin{tabular}{|c|c|c|}
\hline Field & Data Type & Validation \\
\hline ID & int & PK \\
\hline Idsupplier & int & FK in Supplier \\
\hline Date_transaction & date & \\
\hline Quantity order & int & \\
\hline
\end{tabular}


Table 3. Data Structures in Product Offered

\begin{tabular}{|c|c|c|}
\hline Field & Data Type & Validation \\
\hline ID & int & PK \\
\hline code & Varchar(12) & \\
\hline Idsupplier & int & FK in Supplier \\
\hline Status & Varchar(1) & \\
\hline
\end{tabular}

Table 4. Data Structures in Product Offered Details

\begin{tabular}{|c|c|c|}
\hline Field & Data Type & Validation \\
\hline ID & int & PK \\
\hline Idproduct_offerd & int & $\begin{array}{c}\text { FK in Product } \\
\text { Offered }\end{array}$ \\
\hline Idproduct & int & FK in Product \\
\hline Quota & int & \\
\hline
\end{tabular}

Table 5. Data Structures in Supplier Product Offer

\begin{tabular}{|c|c|c|}
\hline Field & Data Type & Validation \\
\hline ID & int & PK \\
\hline Code & Varchar(12) & \\
\hline Idsupplier_product & int & $\begin{array}{c}\text { FK in Supplier's } \\
\text { Product }\end{array}$ \\
\hline Idproduct_ordered & int & $\begin{array}{c}\text { FK in } \\
\text { Product_Ordered }\end{array}$ \\
\hline Quantity & int & \\
\hline Status & Varchar(1) & \\
\hline
\end{tabular}

Table 6. Data Structures in Supplier's Product

\begin{tabular}{|c|c|c|}
\hline Field & Data Type & Validation \\
\hline ID & int & PK \\
\hline Idsupplier & int & FK in Supplier \\
\hline Idproduct & int & FK in Product \\
\hline Subcode & Varchar(5) & \\
\hline Price & Decimal(8,2) & \\
\hline Rank & smallint & \\
\hline Quota & int & \\
\hline
\end{tabular}

Table 7. Data Structures in Product

\begin{tabular}{|c|c|c|}
\hline Field & Data Type & Validation \\
\hline ID & int & PK \\
\hline Code & Varchar(5) & - \\
\hline Name & Varchar(50) & \\
\hline Price & Decimal(8,2) & \\
\hline Information & Text & \\
\hline Status & Varchar(1) & \\
\hline
\end{tabular}

Table 8. Data Structures in Consumen

\begin{tabular}{|c|c|c|}
\hline Field & Data Type & Validation \\
\hline ID & int & PK \\
\hline Code & Varchar(5) & \\
\hline Name & Varchar(50) & \\
\hline
\end{tabular}

Table 9. Data Structures in Product Ordered

\begin{tabular}{|c|c|c|}
\hline Field & Data Type & Validation \\
\hline ID & int & PK \\
\hline Idconsumen & int & FK in Consumen \\
\hline code & Varchar(12) & \\
\hline Order_status & Varchar(1) & \\
\hline
\end{tabular}

Table 10. Data Structures in Product Ordered Details

\begin{tabular}{|c|c|c|}
\hline Field & Data Type & Validation \\
\hline ID & int & PK \\
\hline Idproduct_ordered & int & $\begin{array}{c}\text { FK in Product } \\
\text { Ordered }\end{array}$ \\
\hline Idproduct & int & FK in Product \\
\hline Quantity & int & \\
\hline Status & Varchar(1) & \\
\hline
\end{tabular}

\section{SIMULATION OF AUTOMATED SUPPLIER'S SELECTION IN SUPPLY CHAIN APPLICATION}

Starting from the wholesaler registers what are the products that are sold to its customers. Suppliers choose which are the products that they supply based on products which have been registered. Then a registered supplier chooses whichever product that they supply and how much quota that they provide in these transactions on the same time. Application will stores these offers as data supplied by the supplier and make data supplied as the last rank of product in the same kind after the product has been supplied by another supplier.

Once the applications store data supplier's product. Wholesaler can change the ranking of the data manually. The ranking is based on the integrity of the supplier in terms of products's quality supplied, timeliness of supply. The higher value of rank which given by the wholesaler means the better the supplier's services.

When consumers order the product after the transaction is saved, the application will make the process of supplier selection based on rank and quotas. Process of checking begins from the first rank, whether the supplier is still able to accept the order or not. If yes then the order will be forwarded to the supplier. But if not, then the order will be forwarded to the rank below. This process is repeated until the entire order can be covered.

Example simulations described as follows, UD Jaya which is one of the wholesaler of consumer PT Cahaya Bali Wholesaler. Then UD Jaya booking transactions by selecting menu for new orders

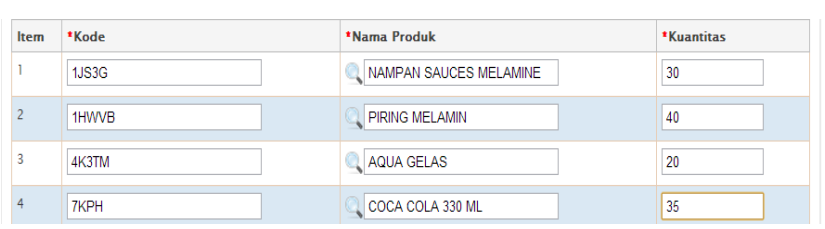

Fig. 12 Consumen's Order

Applications will select the top ranking supplier to supply the product, but before the request is sent to the supplier in question, the application should first check the quota suppliers in record_transaksi_supplier table. In this case, there are no 
transactions that happened that day so, the supplier chosen by ranking the order quantity based quota owned suppliers.

Tabel 11. Supplier's Selection

\begin{tabular}{|l|l|l|l|}
\hline $\begin{array}{l}\text { Product } \\
\text { Name }\end{array}$ & Supplier & $\begin{array}{l}\text { Consumen's } \\
\text { Quantity }\end{array}$ & $\begin{array}{l}\text { Supplier's } \\
\text { Quantity }\end{array}$ \\
\hline $\begin{array}{l}\text { Nampan } \\
\text { Sauce } \\
\text { Melamin }\end{array}$ & $\begin{array}{l}\text { PT Selalu } \\
\text { Maju }\end{array}$ & 30 & 30 \\
\hline $\begin{array}{l}\text { Piring } \\
\text { Melamin }\end{array}$ & $\begin{array}{l}\text { PT Bali } \\
\text { Sejahtera } \\
\text { PT Makmur }\end{array}$ & 40 & \\
\hline Aqua Gelas & $\begin{array}{l}\text { PT Suka } \\
\text { Maju }\end{array}$ & 20 & 20 \\
\hline Coca cola & $\begin{array}{l}\text { PT Suka } \\
\text { Maju }\end{array}$ & 35 & 20 \\
\hline
\end{tabular}

Then after the above process, the request was sent to the relevant suppliers and renewed record supplier's order in the table.

\begin{tabular}{|c|c|c|c|c|c|}
\hline idsupplier & tgl_trangk & Kuantitas pesanan & created_at & updated_at & idproduk \\
\hline & $22012-12-04$ & & 30 2012-12-04 12:43:11 & $2012-12-04 \quad 12: 43: 11$ & 1 \\
\hline & $32012-12-04$ & & 20 2012-12-04 12:43:11 & $2012-12-04 \quad 12: 43: 11$ & 2 \\
\hline & 4 2012-12-04 & & 20 2012-12-04 12:43:11 & $2012-12-04 \quad 12: 43: 11$ & 2 \\
\hline & $12012-12-04$ & & 20 2012-12-04 12:43:11 & 2012-12-04 12:43:11 & 5 \\
\hline & $12912-12-114$ & & $3.52012-12-104 \quad 12: 43: 11$ & $2012-12-114 \quad 12: 43: 11$ & १ \\
\hline
\end{tabular}

Fig. 13 Record of Order to Supplier

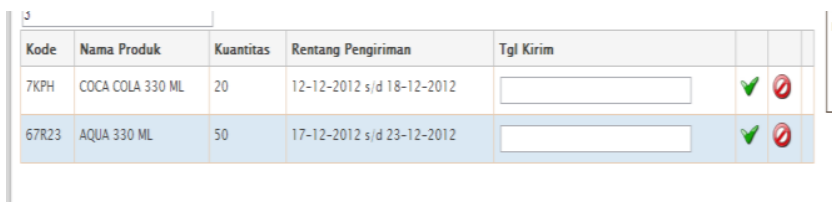

Fig. 14 Request to PT Suka Maju

\section{CONCLUSIONS}

This supply chain application supplier ranking and quota as its approach in the selection of suppliers who will supply the products ordered by consumers. When consumers order one type of product, then the application will sort the supplier based on ranking and quota checking capabilities in a single supplier. Ranking of suppliers are entered manually by the application to be expected that the future of these applications can be combined with calculations made by the intelligent systems in terms of setting ranking. Supplier selection can automatically make the process of booking transactions from the consumer to the supplier more quickly done. The process is done to check whether the record table does not supply more quantity of quota owned suppliers. The system will automatically send a request to the supplier on the number of orders that have previously been treated by quotas and rank. And provide feedback if the supplier does not receive the order.

\section{REFERENCES}

[1] David Zhu. 2008. Agent Based Modeling for Supply Chain Management: Examining The Impact of Information Sharing

[2] Gopal K. Kanji, Alfred Wong, "Business Excellence Model for Supply Chain Management", Total Quality Management. Vol. 10, No.8, 1999,pp. 1147 - 1168.

[3] Luis H. Bibiano, Alberto Caldelas, Enric Mayol and Joan A. 2007. Comparative Analysis of CRM And SCM Systems Implementation Approaches.

[4] Martin Verwijmeren, "Software Component Architecture in Supply Chain Management", Computers in Industry, Vol. 53, 2004,pp. 165-178.

[5] Marquez, Adolfo Crespo. 2010. Dynamic Modelling for Supply Chain Management. Springer.

[6] Michael N. Huhns, Larry M. Stephens, Nenad Ivezic. 2000. Automating Supply-Chain Management

[7] Reza Farzipoor Saen. 2008. Using Data Envelopment Analysis for Ranking Suppliers in the Presence of Nondiscretionary Factors

[8] Ritu Sindhu, Abdul Wahid, GN Purohit. 2009. MultiAgent System Interaction in Integrated SCM

[9] Scott, Colin, Henriette Lundgren, Paul Thompson. . 2011. Guide to Supply Chain Management. Springer

[10] Sotiris Politis, Matthias Klumpp, Dilay Celebi, "Analytical Hierarchy Process in Supplier Evaluation", Innsbruck (Eigenverlag), Vol. 3, 2010, pp.411-424

[11] Tunggal, Amin Widjaja. 2011. Dasar-Dasar Integrated Supply Chain Management. Jakarta: Harvarindo.

[12] Xu Hui, Zhang Jun. 2005. A Study on The Supply Chain Management and Integration of The Chinese Textile Industry in The Post-quota Era 